\title{
Pseudoxanthomonas indica sp. nov., isolated from a hexachlorocyclohexane dumpsite
}

\author{
Kirti Kumari, Pooja Sharma, Kshitiz Tyagi and Rup Lal \\ Department of Zoology, University of Delhi, Delhi-110 007, India
}

Correspondence

Rup Lal

ruplal@gmail.com

\begin{abstract}
A bacterial strain, designated $\mathrm{P} 15^{\top}$, was isolated from the soil of an open hexachlorocyclohexane dumpsite. Comparative sequence analysis showed that strain $\mathrm{P}_{15}{ }^{\top}$ displayed high $16 \mathrm{~S}$ rRNA gene sequence similarities (94.4-97.2\%) with members of the genus Pseudoxanthomonas. The isolate was most closely related to Pseudoxanthomonas mexicana AMX 26B ${ }^{\top}$ (97.2\% 16S rRNA gene sequence similarity) and Pseudoxanthomonas japonensis $12-3^{\top}(97.2 \%)$. DNA-DNA relatedness studies showed unambiguously that strain $\mathrm{P}_{1} 5^{\top}$ represented a novel species that was separate from $P$. mexicana DSM $17121^{\top}(7.7 \%)$ and $P$. japonensis DSM $17109^{\top}(9.4 \%)$. The predominant cellular fatty acids of strain $\mathrm{P} 15^{\top}$ were iso- $\mathrm{C}_{16: 0}(21.4 \%)$, iso- $\mathrm{C}_{15: 0}(16.1 \%)$, summed feature 9 (comprising iso- $\mathrm{C}_{17: 1} \omega 9 \mathrm{c}$ and/or 10-methyl $\left.\mathrm{C}_{16: 0} ; 14.9 \%\right)$, iso- $\mathrm{C}_{11: 0} 3-\mathrm{OH}(8.3 \%)$ and iso- $\mathrm{C}_{14: 0}(7.0 \%)$. The polar lipid profile of strain $\mathrm{P} 15^{\top}$ showed the presence of large amounts of phosphatidylethanolamine, phosphatidylglycerol and diphosphatidylglycerol in addition to unknown glycolipids, phospholipids and an amino-group-containing polar lipid. Ubiquinone 8 was found as the major quinone. The polyamine profile showed the presence of spermidine. The DNA G+C content was $62.9 \pm 2$ mol\%. Strain $\mathrm{P} 15^{\top}$ is described as representing a new member of the genus Pseudoxanthomonas, for which the name Pseudoxanthomonas indica sp. nov. is proposed. The type strain is $\mathrm{P}^{\top} 5^{\top}\left(=\operatorname{MTCC} 8596^{\top}=\mathrm{CCM} 7430^{\top}\right)$.
\end{abstract}

The genus Pseudoxanthomonas (Finkmann et al., 2000) belongs to the family Xanthomonadaceae in the order Xanthomonadales (Garrity \& Holt, 2001). Members of this genus comprise aerobic, Gram-negative, non-sporeforming rods and have been isolated from a variety of habitats such as biofilters (Finkmann et al., 2000), hot springs (Chen et al., 2002), compost (Weon et al., 2006) and soil samples (Thierry et al., 2004; Yang et al., 2005; Chang et al., 2005; Harada et al., 2006). The genus is known for the presence of $3-\mathrm{OH}$ fatty acids as the major hydroxylated components and ubiquinone 8 (Q-8) as the major respiratory quinone (Lee et al., 2008), reduction of nitrite and lack of iso- $\mathrm{C}_{13: 0}$ 3-OH (Thierry et al., 2004), albeit with a few exceptions (Chang et al., 2005; Young et al., 2007; Lee et al., 2008). The genus is currently represented by 13 recognized species: Pseudoxanthomonas broegbernensis (Finkmann et al., 2000; Thierry et al., 2004), P. taiwanensis (Chen et al., 2002), P. japonensis and P. mexicana (Thierry et al., 2004), P. daejeonensis and P. koreensis (Yang et al., 2005), P. kaohsiungensis (Chang et al., 2005), P. suwonensis (Weon et al., 2006), P. kalamensis (Harada et al., 2006), P. dokdonensis (Yoon et al., 2006; Lee et al., 2008),

Abbreviation: RDP, Ribosomal Database Project.

The GenBank/EMBL/DDBJ accession number for the 16S rRNA gene sequence of strain $\mathrm{P} 15^{\top}$ is EF424397.

A supplementary table and two supplementary figures are available with the online version of this paper.
P. yeongjuensis (Yoo et al., 2007), P. spadix (Young et al., 2007) and P. sacheonensis (Lee et al., 2008).

A soil sample was collected from an open hexachlorocyclohexane dumpsite in north India $\left(27^{\circ} 00^{\prime} 24.0^{\prime \prime} \mathrm{N}\right.$ $\left.81^{\circ} 09^{\prime} 03.8^{\prime \prime} \mathrm{E}\right)$, serially diluted and plated on nystatinamended LB agar (Dadhwal et al., 2009). A dull yellowcoloured colony, designated $\mathrm{P} 15^{\mathrm{T}}$, appeared within $36 \mathrm{~h}$ of incubation at $28{ }^{\circ} \mathrm{C}$ and was purified by repeated streaking on LB agar.

The 16S rRNA gene sequence of strain $\mathrm{P} 15^{\mathrm{T}}$ was amplified using the $8 \mathrm{~F}$ and $1492 \mathrm{R}$ universal primer set by colony PCR and sequenced as described elsewhere (Kumar et al., 2008; Jit et al., 2008). The sequence thus obtained was assembled manually using Clone Manager version 5. A continuous sequence of $1392 \mathrm{bp}$ of the 16S rRNA gene was obtained and subjected to similarity searches using the sequence match tool of Ribosomal Database Project II (RDP; http:// rdp.cme.msu.edu/) and BLAST program of National Center of Biotechnological Information (http://www.ncbi.nlm.nih. gov/). A non-redundant BLASTN search of full sequences in GenBank (Altschul et al., 1990; Benson et al., 1999) and RDP II (Maidak et al., 2001) identified the closest relatives of the isolate. Analysis of the $16 \mathrm{~S}$ rRNA gene sequence (1392 bp) revealed that strain $\mathrm{P} 15^{\mathrm{T}}$ showed highest sequence similarity with $P$. mexicana AMX $26 \mathrm{~B}^{\mathrm{T}}(97.2 \%$ $16 \mathrm{~S}$ rRNA gene sequence similarity) and $P$. japonensis $12-3^{\mathrm{T}}(97.2 \%)$. The nearly full-length $16 \mathrm{~S}$ rRNA gene 
sequences of strains closely related to the isolate were retrieved for further analysis. The $16 \mathrm{~S}$ rRNA gene sequence similarity between strain $\mathrm{P} 15^{\mathrm{T}}$ and members of the genus Pseudoxanthomonas was 94.4-97.2\%. Multiple alignment of these sequences was performed using CLUSTAL_X (Thompson et al., 1997), common gaps were removed and the alignment was checked manually for quality. Pairwise evolutionary distances were calculated using the distance model of Jukes \& Cantor (1969) within the TREECON version 1.3b (Van de Peer \& De Wachter, 1994). A phylogenetic tree was constructed using the neighbourjoining method of Saitou \& Nei (1987) and the resultant tree topology was evaluated by bootstrap analysis with 100 resamplings. Strain $\mathrm{P}^{1} 5^{\mathrm{T}}$ clustered with members of the genus Pseudoxanthomonas and formed a monophyletic clade within the cluster containing P. mexicana AMX $26 \mathrm{~B}^{\mathrm{T}}$ and P. japonensis $12-3^{\mathrm{T}}$ (Fig. 1). It is notable that, although the genus Pseudoxanthomonas is not monophyletic and the taxonomic situation of this group is subject to future revision, strain $\mathrm{P} 15^{\mathrm{T}}$ fell within the cluster that exclusively contained members of the genus Pseudoxanthomonas. A similar tree topology was also observed using the maximum-likelihood method in PHYLIP version 3.5 (Felsenstein, 1993) (data not shown).

DNA-DNA hybridization was performed between strain $\mathrm{P}^{\mathrm{T}}{ }^{\mathrm{T}}$ and $P$. mexicana DSM $17121^{\mathrm{T}}$ and P. japonensis DSM $17109^{\mathrm{T}}$, which were obtained from the DSMZ. Extraction, purification and hybridization of total genomic DNA followed the protocol described by Prakash et al. (2007) and Kumar et al. (2008). The amount of bound probe DNA was calculated using a scintillation counter (1450 LSC Luminescence counter Wallac Microbeta Trilux; PerkinElmer). DNA-DNA relatedness was calculated on the basis of the means of four replicates and ranged from 7.7 to $9.4 \%$. Pooled standard deviations of all the hybridization experiments were found to vary by up to $12 \%$. Since all hybridization values were $<70 \%$, the results confirmed that strain $\mathrm{P} 15^{\mathrm{T}}$ represented a novel species of the genus Pseudoxanthomonas, as recommended for the delineation of species (Wayne et al., 1987; Stackebrandt \& Goebel, 1994).

Fatty acid methyl ester analysis was performed as described by Prakash et al. (2007). The fatty acids of strain $\mathrm{P} 15^{\mathrm{T}}$ $(>1.5 \%)$ were iso- $\mathrm{C}_{16: 0}(21.4 \%)$, iso- $\mathrm{C}_{15: 0}(16.1 \%)$,

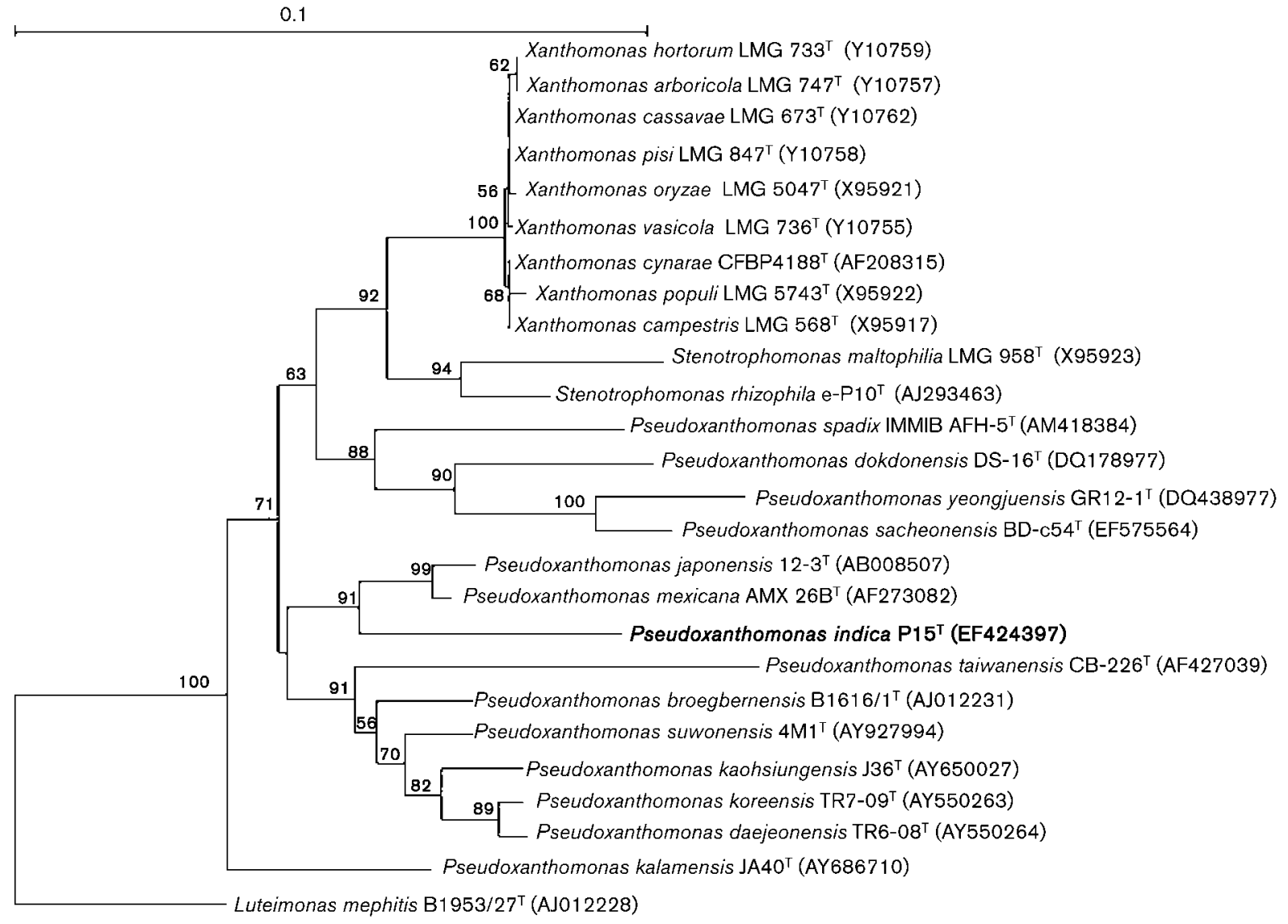

Fig. 1. Phylogenetic tree based on nearly complete $16 \mathrm{~S}$ rRNA gene sequences showing the relationship of strain $P 15^{\top}$ to members of the genus Pseudoxanthomonas and related genera. Bootstrap values $(>50 \%)$ based on 100 resamplings are shown at branch nodes. Luteimonas mephitis $\mathrm{B} 1953^{\top}$ was used as an outgroup. Bar, 0.1 substitutions per nucleotide position. 
summed feature 9 (comprising iso- $\mathrm{C}_{17: 1} \omega 9 c$ and/or 10methyl $\left.\mathrm{C}_{16: 0} ; 14.9 \%\right)$, iso- $\mathrm{C}_{11: 0} 3-\mathrm{OH}(8.3 \%)$, iso- $\mathrm{C}_{14: 0}$ $(7.0 \%)$, iso- $\mathrm{C}_{11: 0}(5.0 \%)$, iso- $\mathrm{C}_{16: 1} \mathrm{H}(3.5 \%)$, iso- $\mathrm{C}_{10: 0}$ $(3.4 \%)$, iso- $\mathrm{C}_{12: 0} 3-\mathrm{OH}(3.4 \%)$, summed feature 3 (comprising $\mathrm{C}_{16: 1} \omega 7 c$ and/or $\mathrm{C}_{16: 1} \omega 6 c ; 3 \%$ ), anteiso$\mathrm{C}_{15: 0}(2.9 \%)$, iso- $\mathrm{C}_{15: 1} \mathrm{~F}(2.4 \%)$ and $\mathrm{C}_{16: 0}(1.6 \%)$. Strain $\mathrm{P} 15^{\mathrm{T}}$ contained large amounts of iso- $\mathrm{C}_{15: 0}$ and iso- $\mathrm{C}_{16: 0}$, which are also predominant fatty acids in members of other species of the genus Pseudoxanthomonas. A comparison of the fatty acid profiles of strain $\mathrm{P} 15^{\mathrm{T}}$ with all members of the genus Pseudoxanthomonas is given in Supplementary Table S1 (available in IJSEM Online).

Polar lipid analysis of strain $\mathrm{P} 15^{\mathrm{T}}$ was performed by twodimensional TLC using $1.0 \%$ Premulin as the spray reagent for detection of total lipids under UV (Gupta et al., 2009; Sharma et al., 2010; Nigam et al., 2010). The major polar lipids were phosphatidylethanolamine, phosphatidylglycerol and diphosphatidylglycerol, in addition to small amounts of unknown glycolipids, phospholipids and an amino-group-containing polar lipid (Supplementary Fig. S1). The lipid profile of strain $\mathrm{P}^{1} 5^{\mathrm{T}}$ was found to be similar to those of $P$. mexicana and $P$. sacheonensis (Lee et al., 2008) by having phosphatidylethanolamine, phosphatidylglycerol and diphosphatidylglycerol as the major lipids; however, the unknown glycolipids and phospholipids found in strain $\mathrm{P} 15^{\mathrm{T}}$ were absent in $P$. sacheonensis.

Quinones were extracted according to the method described by Collins \& Jones (1981). Q-8 was found to be the major respiratory quinone. Polyamines were extracted as described by Busse \& Auling (1988) and analysed by TLC (Silica gel $60 \mathrm{~F}_{254}, 20 \times 20 \mathrm{~cm}$; Merck, Germany) and showed the presence of spermidine. The DNA G $+\mathrm{C}$ content was calculated by the method described by Gonzalez \& Saiz-Jimenez (2002) using realtime PCR (7500; Applied Biosystems) and was found to be $62.9 \mathrm{~mol} \%$, which is in accordance with the range described for the genus Pseudoxanthomonas (Finkmann et al., 2000; Thierry et al., 2004).

Colony morphology of strain $\mathrm{P} 15^{\mathrm{T}}$ was studied on LB agar ( $\mathrm{pH}$ 7.5) after $48 \mathrm{~h}$ of incubation at $28{ }^{\circ} \mathrm{C}$. Colonies were dull yellow, circular with entire margins and about $1.5 \mathrm{~mm}$ in diameter (range 1-2 $\mathrm{mm}$ ) after 2 days of incubation. The temperature range for growth was assessed at $10-41{ }^{\circ} \mathrm{C}$. Oxidase activity was tested using oxidase discs from HiMedia. Catalase activity was tested by adding $3 \%(\mathrm{v} / \mathrm{v})$ hydrogen peroxide solution to colonies grown on LB agar (McCarthy \& Cross, 1984). Motility was checked on motility agar (Farmer, 1999). Hydrolysis of gelatin, casein, aesculin and Tween 20 was determined as described by Cowan \& Steel (1965). Urease activity was tested in accordance with Christensen (1946). Indole production was tested as described by Smibert \& Krieg (1994). $\beta$-Galactosidase activity was observed using ONPG discs (HiMedia), according to the manufacturer's instructions. Citrate utilization was tested on Simmons' citrate agar (Simmons, 1926). Nitrate reduction was tested as described by Smibert
\& Krieg (1994). Assimilation of different carbohydrates was tested in basal media (Gordon et al., 1974). Antibiotic sensitivity tests were performed on Muller-Hinton II medium using ready-made Sensi-Discs (HiMedia), containing ( $\mu \mathrm{g}$ per disc, unless otherwise stated) amikacin (30), ampicillin (10), chloramphenicol (30), ciprofloxacin (5), gentamicin (10), kanamycin (30), nalidixic acid (30), penicillin $\mathrm{G}(10 \mathrm{U})$, polymyxin $\mathrm{B}$ (300), rifampicin (5), tetracycline (30) and vancomycin (30). All tests were performed at least in duplicate with strain $\mathrm{P} 15^{\mathrm{T}}, P$. mexicana DSM $17121^{\mathrm{T}}$ and P. japonensis DSM $17109^{\mathrm{T}}$ under similar conditions. The results are summarized in Table 1.

The Gram-stain test was performed using a Gram-staining kit (HiMedia). Cell morphology was examined by light and electron microscopy (TEM 269D; Morgagni, Fei) using cells from an exponentially growing culture on LB agar, negatively stained with $0.5 \%$ uranyl acetate and air dried (Supplementary Fig. S2).

Strain $\mathrm{P} 15^{\mathrm{T}}$ should be classified as a member of the genus Pseudoxanthomonas as it showed an absence of the fatty acid iso- $\mathrm{C}_{13: 0} 3-\mathrm{OH}$ and high $16 \mathrm{~S}$ rRNA gene sequence similarity with members of the genus Pseudoxanthomonas. In addition, the polar lipid pattern, presence of spermidine and Q-8 as the major respiratory quinone further supported the phylogenetic findings. From the data presented here, it is evident that strain $\mathrm{P} 15^{\mathrm{T}}$ exhibits an overall chemotaxonomic profile consistent with those of members of the genus Pseudoxanthomonas and represents a novel species. The name Pseudoxanthomonas indica sp. nov. is proposed.

\section{Description of Pseudoxanthomonas indica sp. nov.}

Pseudoxanthomonas indica (in.di'ca. L. fem adj. indica of India).

Colonies are dull yellow, smooth and circular (1.5 mm on LB agar after $48 \mathrm{~h}$ at $28{ }^{\circ} \mathrm{C}$ ). Cells are Gram-negative-staining, aerobic rods $(1.5 \times 0.5 \mu \mathrm{m})$ and bear a single polar flagellum. The optimum temperature for growth is $28{ }^{\circ} \mathrm{C}$. Cells are catalase- and oxidase-positive. Hydrolyses ONPG ( $\beta$ galactosidase), aesculin and Tween 20 but does not hydrolyse gelatin, casein or urea. Indole production is negative. Positive for nitrate reduction. Assimilates D-glucose, D-mannose, $\mathrm{N}$ acetyl D-glucosamine, maltose, (+)-D-galactose, sucrose, D-fructose, lactose, L-histidine and L-proline, but not Larabinose, D-mannitol, (+)-D-raffinose, L-alanine, L-serine or putrescine. Citrate is not utilized. Sensitive to amikacin, ampicillin, chloramphenicol, ciprofloxacin, gentamicin, kanamycin, nalidixic acid, polymyxin $\mathrm{B}$, rifampicin, tetracycline and vancomycin, but resistant to penicillin $\mathrm{G}$. The predominant cellular fatty acids are iso- $\mathrm{C}_{16: 0}$, iso- $\mathrm{C}_{15: 0}$, summed feature 9 (comprising iso- $\mathrm{C}_{17: 1} \omega 9 c$ and/or 10methyl $\mathrm{C}_{16: 0}$ ), iso- $\mathrm{C}_{11: 0} 3-\mathrm{OH}$ and iso- $\mathrm{C}_{14: 0}$. The polyamine profile shows the presence of spermidine. Q-8 is the major respiratory quinone. The major polar lipids arephosphatidylethanolamine, phosphatidylglycerol and diphosphatidylglycerol, in addition to small amounts of glycolipids, phospholipids and an amino-group-containing polar lipid. 
Table 1. Differential morphological and physiological characteristics of strain $\mathrm{P} 15^{\top}$ and members of the genus Pseudoxanthomonas Strains: $1, \mathrm{P} 15^{\mathrm{T}}$ (data from this study); 2, P. mexicana DSM $17121^{\mathrm{T}}$ (this study); 3, P. japonensis DSM $17109^{\mathrm{T}}$ (this study); 4, P. dokdonensis DS-16 ${ }^{\mathrm{T}}$ (Yoon et al., 2006; Lee et al., 2008); 5, P. kaohsiungensis $\mathrm{J}_{36}{ }^{\mathrm{T}}$ (Chang et al., 2005); 6, P. suwonensis 4M1 ${ }^{\mathrm{T}}$ (Weon et al., 2006); 7, P. daejeonensis TR6-08 ${ }^{\mathrm{T}}$ (Yang et al., 2005); 8, P. broegbernensis B1616/1 ${ }^{\mathrm{T}}$ (Finkmann et al., 2000; Weon et al., 2006; Lee et al., 2008); 9, P. koreensis T7-09 ${ }^{\mathrm{T}}$ (Yang et al., 2005); 10, P. kalamensis JA40 (Harada et al., 2006); 11, P. sacheonensis BD-c54 ${ }^{\mathrm{T}}$ (Lee et al., 2008); 12, P. yeongjuensis GR12- $1^{\mathrm{T}}$ (Yoo et al., 2007); 13, P. spadix IMMIB AFH $-5^{\mathrm{T}}$ (Young et al., 2007); 14, P. taiwanensis CB-226 ${ }^{\mathrm{T}}$ (Chen et al., 2002; Yoo et al., 2007). All strains are Gram-negativestaining rods and, if motile, possess a single polar flagellum. CY, Cream yellow; DY, dull yellow; DYDBP, deep yellow, producing diffusible brown pigment; GY, greenish yellow; LY, light yellow; PY, pale yellow; W, white; Y, yellow; YDBP, yellow, producing date-brown pigment; +, Positive; ( + ), weakly positive; $\mathrm{v}$, variable reaction between duplicates; -, negative; ND, no data available.

\begin{tabular}{|c|c|c|c|c|c|c|c|c|c|c|c|c|c|c|}
\hline Characteristic & 1 & 2 & 3 & 4 & 5 & 6 & 7 & 8 & 9 & 10 & 11 & 12 & 13 & 14 \\
\hline Colony colour & DY & PY & DYDBP & $\mathrm{CY}$ & LY & Y & Y & $\mathrm{Y}$ & $\mathrm{W}$ & PY & $\mathrm{Y}$ & GY & YDBP & LY \\
\hline Motility and flagellation & + & $+^{*}$ & $+^{*}$ & - & + & + & + & + & - & - & - & + & + & - \\
\hline \multicolumn{15}{|l|}{ Assimilation of: } \\
\hline D-Glucose & + & + & + & + & + & + & + & + & - & + & + & + & + & + \\
\hline L-Arabinose & - & + & + & - & - & + & + & + & - & + & - & - & - & - \\
\hline D-Mannose & + & + & + & + & - & - & - & + & - & - & + & - & - & - \\
\hline$N$-Acetyl D-glucosamine & + & + & - & + & + & + & + & + & - & + & + & + & - & - \\
\hline Maltose & + & + & + & + & + & + & + & + & - & + & + & + & - & - \\
\hline Citrate & - & - & - & - & - & - & - & + & - & - & - & - & - & - \\
\hline$(+)$-D-Raffinose & - & + & - & $\mathrm{ND}$ & - & $\mathrm{ND}$ & $\mathrm{ND}$ & $-{ }^{*}$ & ND & + & + & $\mathrm{ND}$ & - & - \\
\hline Sucrose & + & + & - & - & - & ND & - & $+^{*}$ & - & + & ND & $\mathrm{ND}$ & - & - \\
\hline Lactose & + & + & - & - & - & ND & - & $+^{*}$ & - & $\mathrm{ND}$ & + & $\mathrm{ND}$ & - & - \\
\hline Oxidase & + & + & + & + & + & + & + & ND & + & + & + & + & + & + \\
\hline Catalase & + & $(+)$ & - & + & - & + & + & + & + & + & + & + & + & + \\
\hline$\beta$-Galactosidase & + & - & $(+)$ & - & + & + & + & + & - & - & + & + & - & + \\
\hline Casein hydrolysis & - & + & $(+)$ & - & $\mathrm{ND}$ & - & + & - & + & $\mathrm{ND}$ & + & + & $\mathrm{ND}$ & - \\
\hline Urease & - & - & - & - & - & - & - & - & + & - & + & - & - & $\mathrm{ND}$ \\
\hline Gelatin hydrolysis & - & - & - & + & - & + & - & - & - & - & + & + & + & - \\
\hline
\end{tabular}

${ }^{*}$ Data from Thierry et al. (2004).

The type strain, $\mathrm{P} 15^{\mathrm{T}}\left(=\mathrm{MTCC} 8596^{\mathrm{T}}=\mathrm{CCM} 7430^{\mathrm{T}}\right)$, was isolated from the soil of an open hexachlorocyclohexane dumpsite situated in north India. The DNA G + C content of the type strain is $62.9 \pm 2 \mathrm{~mol} \%$.

\section{Acknowledgements}

K. K., P.S. and K. T. gratefully acknowledge the Council of Scientific and Industrial Research (CSIR) and Department of Biotechnology (DBT), Government of India, for providing research fellowships. This study was supported by the National Bureau of Agriculturally Important Micro-organisms (NBAIM), Indian Council of Agricultural Research (ICAR), Government of India (grant no. 6-2/2008/Dir/ NBAIM). We thank Dr J. P. Euzéby for etymological advice.

\section{References}

Altschul, S. F., Gish, W., Miller, W., Myers, E. W. \& Lipman, D. J. (1990). Basic local alignment search tool. J Mol Biol 215, 403410 .
Benson, D. A., Boguski, M. S., Lipman, D. J., Ostell, J., Ouellette, B. F., Rapp, B. A. \& Wheeler, D. L. (1999). GenBank. Nucleic Acids Res 27, 12-17.

Busse, J. \& Auling, G. (1988). Polyamine pattern as a chemotaxonomic marker within the Proteobacteria. Syst Appl Microbiol 11, 1-8.

Chang, J. S., Chou, C. L., Lin, G. H., Sheu, S. Y. \& Chen, W. M. (2005). Pseudoxanthomonas kaohsiungensis, sp. nov., a novel bacterium isolated from oil-polluted site produces extracellular surface activity. Syst Appl Microbiol 28, 137-144.

Chen, M.-Y., Tsay, S.-S., Chen, K.-Y., Shi, Y.-C., Lin, Y.-T. \& Lin, G.-H. (2002). Pseudoxanthomonas taiwanensis sp. nov., a novel thermophilic, $\mathrm{N}_{2} \mathrm{O}$-producing species isolated from hot springs. Int J Syst Evol Microbiol 52, 2155-2161.

Christensen, W. B. (1946). Urea decomposition as a means of differentiating Proteus and para-colon cultures from each other and from Salmonella and Shigella types. J Bacteriol 52, 461-466.

Collins, M. D. \& Jones, D. (1981). Distribution of isoprenoid quinone structural types in bacteria and their taxonomic implication. Microbiol Rev 45, 316-354.

Cowan, S. T. \& Steel, K. J. (1965). Manual for the Identification of Medical Bacteria. London: Cambridge University Press. 
Dadhwal, M., Singh, A., Prakash, O., Gupta, S. K., Kumari, K., Sharma, P., Jit, S., Verma, M., Holliger, C. \& Lal, R. (2009). Proposal of biostimulation for hexachlorocyclohexane $(\mathrm{HCH})$-decontamination and characterization of culturable bacterial community from highdose point HCH-contaminated soils. J Appl Microbiol 106, 381-392.

Farmer, J. J., III (1999). Enterobacteriaceae: introduction and identification. In Manual of Clinical Microbiology, 7th edn, pp. 448452. Edited by P. R. Murray, E. J. Baron, M. A. Pfaller, F. C. Tenover \& R. H. Yolken. Washington, DC: American Society for Microbiology.

Felsenstein, J. (1993). PHYLIP (phylogeny inference package), version 3.5c. Distributed by the author. Department of Genome Sciences, University of Washington, Seattle, USA.

Finkmann, W., Altendorf, K., Stackebrandt, E. \& Lipski, A. (2000). Characterization of $\mathrm{N}_{2} \mathrm{O}$-producing Xanthomonas-like isolates from biofilters as Stenotrophomonas nitritireducens sp. nov., Luteimonas mephitis gen. nov., sp. nov. and Pseudoxanthomonas broegbernensis gen. nov., sp. nov. Int J Syst Evol Microbiol 50, 273-282.

Garrity, G. M. \& Holt, J. G. (2001). The road map to the Manual. In Bergey's Manual of Systematic Bacteriology, 2nd edn, vol. 1, pp. 119166. Edited by D. R. Boone, R. W. Castenholz \& G. M. Garrity. New York: Springer.

Gonzalez, J. M. \& Saiz-Jimenez, C. (2002). A fluorimetric method for the estimation of $\mathrm{G}+\mathrm{C}$ mol\% content in microorganisms by thermal denaturation temperature. Environ Microbiol 4, 770-773.

Gordon, R. E., Barnett, D. A., Handerhan, J. E. \& Pang, C. H.-N. (1974). Nocardia coeliaca, Nocardia autotrophica, and the nocardin strain. Int J Syst Bacteriol 24, 54-63.

Gupta, S. K., Lal, D. \& Lal, R. (2009). Novosphingobium panipatense sp. nov. and Novosphingobium mathurense sp. nov., from oil-contaminated soil. Int J Syst Evol Microbiol 59, 156-161.

Harada, R. M., Campbell, S. \& Li, Q. X. (2006). Pseudoxanthomonas kalamensis sp. nov., a novel gammaproteobacterium isolated from Johnston Atoll, North Pacific Ocean. Int J Syst Evol Microbiol 56, 1103-1107.

Jit, S., Dadhwal, M., Prakash, O. \& Lal, R. (2008). Flavobacterium lindanitolerans sp. nov., isolated from hexachlorocyclohexanecontaminated soil. Int J Syst Evol Microbiol 58, 1665-1669.

Jukes, T. H. \& Cantor, C. R. (1969). Evolution of protein molecules. In Mammalian Protein Metabolism, vol. 3, pp. 21-132. Edited by $\mathrm{H}$. N. Munro. New York: Academic Press.

Kumar, M., Verma, M. \& Lal, R. (2008). Devosia chinhatensis sp. nov., isolated from a hexachlorocyclohexane $(\mathrm{HCH})$ dump site in India. Int J Syst Evol Microbiol 58, 861-865.

Lee, D. S., Ryu, S. H., Hwang, H. W., Kim, Y.-J., Park, M., Lee, J. R., Lee, S.-S. \& Jeon, C. O. (2008). Pseudoxanthomonas sacheonensis sp. nov., isolated from BTEX-contaminated soil in Korea, transfer of Stenotrophomonas dokdonensis Yoon et al. 2006 to the genus Pseudoxanthomonas as Pseudoxanthomonas dokdonensis comb. nov. and emended description of the genus Pseudoxanthomonas. Int J Syst Evol Microbiol 58, 2235-2240.

Maidak, B. L., Cole, J. R., Lilburn, T. G., Parker, C. T., Jr, Saxman, P. R., Farris, R. J., Garrity, G. M., Olsen, G. J., Schmidt, T. M. \& Tiedje, J. M. (2001). The RDP-II (Ribosomal Database Project). Nucleic Acids Res 29, 173-174.

McCarthy, A. J. \& Cross, T. (1984). A taxonomic study of Thermomonospora and other monosporic actinomycetes. J Gen Microbiol 130, 5-25.
Nigam, A., Jit, S. \& Lal, R. (2010). Sphingomonas histidinilytica sp. nov., isolated from a hexachlorocyclohexane dump site. Int J Syst Evol Microbiol 60, 1038-1043.

Prakash, O., Kumari, K. \& Lal, R. (2007). Pseudomonas delhiensis sp. nov., from a fly ash dumping site of a thermal power plant. Int $J$ Syst Evol Microbiol 57, 527-531.

Saitou, N. \& Nei, M. (1987). The neighbor-joining method: a new method for reconstructing phylogenetic trees. Mol Biol Evol 4, 406-425.

Sharma, P., Verma, M., Bala, K., Nigam, A. \& Lal, R. (2010). Sphingopyxis ummariensis sp. nov., isolated from hexachlorocyclohexane (HCH)-dumpsite in North India. 60, 780-784.

Simmons, J. S. (1926). A culture medium for differentiating organisms of typhoid-colon aerogenes groups and for isolating certain fungi. J Infect Dis 39, 209-214.

Smibert, R. M. \& Krieg, N. R. (1994). Phenotypic characterization. In Methods for General and Molecular Bacteriology, pp. 607-654. Edited by P. Gerhardt, R. G. E. Murray, W. A. Wood \& N. R. Krieg. Washington, DC: American Society for Microbiology.

Stackebrandt, E. \& Goebel, B. M. (1994). Taxonomic note: a place for DNA-DNA reassociation and $16 \mathrm{~S}$ rRNA sequence analysis in the present species definition in bacteriology. Int J Syst Bacteriol 44, 846-849.

Thierry, S., Macarie, H., lizuka, T., Geissdörfer, W., Assih, E. A., Spanevello, M., Verhe, F., Thomas, P., Fudou, R. \& other authors (2004). Pseudoxanthomonas mexicana sp. nov. and Pseudoxanthomonas japonensis sp. nov., isolated from diverse environments, and emended descriptions of the genus Pseudoxanthomonas Finkmann et al. 2000 and of its type species. Int J Syst Evol Microbiol 54, 2245-2255.

Thompson, J. D., Gibson, T. J., Plewniak, F., Jeanmougin, F. \& Higgins, D. G. (1997). The CLUSTAL_X windows interface: flexible strategies for multiple sequence alignment aided by quality analysis tools. Nucleic Acids Res 25, 4876-4882.

Van de Peer, Y. \& De Wachter, R. (1994). TREECON for Windows: a software package for the construction and drawing of evolutionary trees for the Microsoft Windows environment. Comput Appl Biosci 10, 569-570.

Wayne, L. G., Brenner, D. J., Colwell, R. R., Grimont, P. A. D., Kandler, O., Krichevsky, M. I., Moore, L. H., Moore, W. E. C., Murray, R. G. E. \& other authors (1987). International Committee on Systematic Bacteriology. Report of the ad hoc committee on reconciliation of approaches to bacterial systematics. Int J Syst Evol Microbiol 37, 463-464.

Weon, H. Y., Kim, B.-Y., Kim, J.-S., Lee, S.-Y., Cho, Y.-H., Go, S.-J., Hong, S.-B., Im, W.-T. \& Kwon, S.-W. (2006). Pseudoxanthomonas suwonensis sp. nov., isolated from cotton waste composts. Int J Syst Evol Microbiol 56, 659-662.

Yang, D.-C., Im, W.-T., Kim, M. K. \& Lee, S.-T. (2005). Pseudoxanthomonas koreensis sp. nov. and Pseudoxanthomonas daejeonensis sp. nov. Int J Syst Evol Microbiol 55, 787-791.

Yoo, S.-H., Weon, H.-Y., Kim, B.-Y., Kim, J.-H., Baek, Y.-K., Kwon, S.-W., Go, S.-J. \& Stackebrandt, E. (2007). Pseudoxanthomonas yeongjuensis sp. nov., isolated from soil cultivated with Korean ginseng. Int J Syst Evol Microbiol 57, 646-649.

Yoon, J.-H., Kang, S.-J., Oh, H. W. \& Oh, T.-K. (2006). Stenotrophomonas dokdonensis sp. nov., isolated from soil. Int J Syst Evol Microbiol 56, 1363-1367.

Young, C. C., Ho, M.-J., Arun, A. B., Chen, W.-M., Lai, W.-A., Shen, F.-T., Rekha, P. D. \& Yassin, A. F. (2007). Pseudoxanthomonas spadix sp. nov., isolated from oil-contaminated soil. Int J Syst Evol Microbiol 57, 18231827. 